\title{
Okul Öncesi Öğretmen Adaylarının Eğitimlerinin Sınıf Yönetimi ve Stratejileri Üzerindeki Etkisine İlişkin Görüşlerinin İncelenmesi* $^{*}$
}

\author{
The Impact of Teaching Education Program on Pre-service \\ Teachers' Classroom Management Views and Classroom \\ Management Strategies
}

DOI: http://dx.doi.org/10.17556/jef.03025

Yasin Öztürk**, Merve Gangal ***, Meral Beşken Ergişi****

Özet

Bu çalışma ile okul öncesi öğretmen adaylarının aldıkları eğitimlerin ve uygulama deneyimlerinin sınıf yönetimi, sınıfta disiplini sağlama, sorunlarla başa çıkma ve problem çözme yeterlilikleri üzerine etkisi incelenecektir. Araştırmada nitel araştırma yöntemlerinden özel durum çalışması (Case Study) kullanılmıştır. Araştırmanın verileri odak grup görüşmeleri ile elde edilmiştir. Çalışmanın katılımcılarını bir üniversitenin eğitim fakültesinde okul öncesi öğretmenliği ana bilim dalında eğitimini sürdürmekte olan sekiz son sınıf öğrencisi oluşturmaktadır. Görüşme için odak grup oluşturulmuş ve bu grupla 3 oturum halinde görüşmeler yapılmıştır. Tüm görüşmeler video kayıt cihazı ile kayıt altına alınmış ve sonrasında yazıya dökülmüştür. Araştırmadan elde edilen bulgular doğrultusunda verilerin nitel veri analiz aracı NVivo 8 ile analizi yapılmıştır. Araştırmanın sonuç kısmında elde edilen bulguların değerlendirilmesi yapılmıştır.

Anahtar Sözcükler: Okul Öncesi Eğitim, Öğretmen Eğitimi, Sınıf Yönetimi

\begin{abstract}
This study examines the effect of pre-service teachers' education and student teaching on their views about classroom management, classroom management strategies and skills, and problem solving skills. Case study, a form of qualitative research, is used as the research method in this study. Participants of this study included 8 pre-service teachers studying in Early Childhood Teacher Education Program in one of the universities in Turkey. Data were collected through three focus group interviews. Interviews were video-recorded and later transcribed for coding and analysis. Nvivo 8 program is used to code and analyze the data. Participants of this study felt that the education they are receiving is too theoretical and is not put into practice. Moreover, they stated that the content of the classroom management class is not suited to early childhood education.
\end{abstract}

Keywords: Early Childhood Education, Teacher Education, Classroom

Management

*Bu makalenin bir bölümü 3. Uluslararası Okul Öncesi Eğitim Kongresinde sözel bildiri olarak sunulmuştur.

${ }^{* *}$ Yrd. Doç. Dr., Karadeniz Teknik Üniversitesi, byozturk@ktu.edu.tr

*** Öğr. Gör., Karadeniz Teknik Üniversitesi, mervegangal@gmail.com

**** Yrd. Doç. Dr., Karadeniz Teknik Üniversitesi, beskenmeral@yahoo.com 


\section{Giriş}

Okul öncesi eğitim çocuğun doğduğu andan, ilköğretime başladığı güne kadar geçen yılları kapsayan ve çocuğun büyük oranda gelişimini tamamladığı, kişiliğini kazandığı, eğitim süreci olarak tanımlanır (Bilir, 1993). Çocukların ilk eğitim ortamı olan ailede verilen temel eğitimden sonra çocukların ikinci eğitim ortamları okul olur. Okul çocukların toplumsallaşma sürecini ilk yaşayacağı ve aileden gördükleri kültürel değerleri yansitacağı ilk kurumdur. Çocuklar okul ortamında kendi çevresi dışında farklı bir çevre olduğunu ve bu çevrenin uyulması gereken farklı kurallara sahip olduğunu fark ederler. Bu dönemde çocuklar kendi yapılandırdıkları birikimin üzerine yeni bilgileri alırken kendini korumayı, paylaşmayı, hakkına sahip çıkmayı ve başkalarının fiziksel ve duygusal haklarına zarar vermemeyi öğrenirler (Yavuzer, 2006). Bu dönemde çocuğun bedensel, zihinsel, duygusal ve sosyal becerilerinin gelişmesi, ileriki dönemlerdeki becerilerine temel oluşturması açısından çok önemlidir.

Eğitimcilerin çocuğu araştırmacı, problem çözme ve yeniliklere adaptasyonu kuvvetli, kendine güvenen ve kendini ifade edebilen, doğru kararlar alabilen, girişimci bireyler olarak yetiştirilebilmeleri okul öncesi dönemde verilen eğitimle daha etkili ve faydalı olacaktır. Bununla birlikte bu dönemde alınan eğitim, çocuğun doğru alışkanlıklar kazanmasında, ihtiyacı olan davranışları edinmesinde ve öğrendiklerini uygulamada özgürlük ve cesaret kazanmasını sağlayacaktır (Early ve diğerleri, 2006). Bu açıdan bakıldığında okul öncesi eğitim çocuk eğitiminin temelidir.

Çocuklar okul öncesi eğitim kurumlarına geldiklerinde yanlarında doğup büyüdükleri çevrenin kültürel ve sosyal etkilerini de getirirler. Farklı çevrelerden gelen bu çocuklar sınıf ortamında kendi yaşantıları ve öğrendikleri doğrultusunda hareket etme eğilimindedirler. Bu durum eğitim-öğretim faaliyetlerini düzenli bir şekilde yürütmek isteyen öğretmenin çeşitli sorunlarla karşılaşmasına neden olur (Aktaş Arnas ve Sadık, 2008). Sınıf içerisinde karşılaşılan problemlerin çocukların gelişimine olumlu katkısı olan ve doğru alışkanlıklar kazanmasına yardımcı olacak yöntem ve tekniklerle ortadan kaldırılmaya çalışılması önemlidir.

Çocukların yaşantısında belirleyici olan ilk okul deneyiminin çocukların eğitim ve yaşam ortamlarında bilinçli düzenlemeler yapılarak sürdürülmesi çocukların kendi yaşantılarında ve toplumsal düzende daha iyi bir geleceğe sahip olması için gereklidir (Gezgin, 2009). Bu durumda okul öncesi öğretmenlerinin sınıf içersinde karşılaştıkları sorunlar ile başa çıkabilmeleri için etkili sınıf yönetimi 
becerilerine ve gerekli öğretmenlik yeterliliğine sahip olması gerekmektedir. Öğretmenin hazırladığı sınıf ortamının verimli olabilmesi için öğretmenin bu ortamda muhtemel kriz anlarını iyi yönetebilmesi ve var olan mesleki bilgilerini doğru zamanda ve yerde kullanabilmesi gerekmektedir (Güven,2005).

Okul öncesi öğretmenlerin mesleğe başladıklarında disiplini sağlama ve sınıf yönetimi konusunda yeterli ve etkili olabilmeleri için aldıkları üniversite eğitimi ve bu alanda kendilerini geliştirmeleri çok önemlidir. Çünkü öğretmenlerin bilgi, beceri ve davranış anlamında eksikliklerinin bulunduğu bir ortamda nitelikli eğitim-öğretim faaliyeti yürütmek mümkün olmayacaktır (Akbaşl1, 2010). Bu durum öğretmenlerin mesleğe başlarken en iyi şekilde donanımlı olmasının ne kadar önemli olduğunu ortaya koymaktadır.

Okul öncesi öğretmen adaylarının üniversitede aldıkları teorik ve uygulamalı eğitimler, adayların bilgi ve becerilerini geliştirirken, adaylara farklı bakış açıları, çeşitli düşünme becerileri ve kendi yeterliliklerini fark etme olanakları da kazandırabilir. Fakat günümüzde öğretmenlik mesleğini yürütebilmek için yalnızca belli konuda bilgi sahibi olunmasının yeterli olduğu düşüncesi pek çok kişi tarafından desteklenmektedir (Ekici, 2008). Oysaki öğretmenlerin sahip oldukları bilgileri aktarabilmeleri için farklı becerilere sahip olması gerekmektedir. Etkili sınıf yönetimi ve disiplini sağlama yeterliliği de bu beceriler arasında öne çıkmaktadır. Çünkü sınıf disiplinini sağlamakta zorlanan bir öğretmen enerjisini sınıf yönetimini sağlamaya harcayacağından eğitim faaliyetlerine ayıracağı zaman azalır. $\mathrm{Bu}$ durum da etkili eğitim faaliyetlerinin gerçekleştirilememesine ve çocuklara kazandırılması hedeflenen çeşitli davranışların göz ardı edilmesine yol açar.

Okul öncesi dönemde çocukların hayatları boyunca kullanacakları temel beceri ve davranışları kazandıklarını düşünürsek okul öncesi öğretmenlerinin sınıf yönetimi ile ilgili bilgi ve becerilerinin çocukların gelişimde ne kadar etkili olduğunu anlayabiliriz. Bu durum okul öncesi öğretmen adaylarının sınıf yönetimi ile ilgili aldıkları derslerin amacına uygun ve etkili olmasının çocukların sosyal-duygusal gelişiminde ve kişilik oluşumunda önemli bir yere sahip olduğunu gösterir. Çünkü mesleğe yeni başlamış bir öğretmenin sınıfta çocuklarla karşı karşıya geldiğinde kendini planladığı eğitim faaliyetlerini yürütmek için yeterli hissetmesi ve eğitimci olarak kendine güvenmesi çocuklar üzerinde de etkili olacaktır (Sadık, 2008). Meslek hayatına sınıf yönetimi ve disiplin ile ilgili yeterli bilgi ve donanımla başlayan bir öğretmen sınıfta görülen istenmeyen bir davranış karşısında nasıl davranması gerektiğini 
bildiğinden sınıfta oluşan kargaşa ortamını en iyi şekilde yönetecek ve çocukların bu kargaşa ortamından faydalı davranışlar kazanmasını sağlayacaktır.

$\mathrm{Bu}$ çalışma ile okul öncesi öğretmen adaylarının aldıkları eğitimlerin ve uygulama deneyimlerinin sinıf yönetimi, sınıfta disiplini sağlama, sorunlarla başa çıkma ve problem çözme yeterlilikleri üzerine etkisi incelenecektir.

- Okul öncesi öğretmen adayları sınıf yönetimi konusunda aldıkları eğitimi nasıl tarif etmektedirler?

- Okul öncesi eğitim sınıfında ortaya çıkabilecek istenmeyen davranışları öğretmen adayları nasıl tanımlarlar ve istenmeyen davranışlarla başa çıkma stratejileri nelerdir?

- Öğretmen adaylarının aldıkları eğitimlerin ve öğretmenlik uygulama deneyimlerinin sınıf yönetimi ile ilgili görüş, inanç ve yeterlilikleri üzerindeki etkileri nelerdir?

\section{Yöntem}

\section{Araştırmanın içeriği}

Araştırmada nitel araştırma yöntemlerinden özel durum çalışması yöntemi kullanılmıştır. Araştırmanın verileri odak grup görüşmeleri ile elde edilmiştir.

\section{Araștırmanın modeli}

Özel durum çalışması ile öğretmen adaylarının düşünce ve inançlarını kendi ortamlarında, çok yönlü, detaylı, sistemli ve derinlemesine incelenmesi amaçlanmıştır (Berg, 2001).

\section{Çalışma Grubu}

2011-2012 eğitim öğretim y1lında eğitim fakültelerinin okul öncesi öğretmenliği ana bilim dalında eğitimini sürdürmekte olan 4 . Sınıf öğrencileri ile yürütülen araştırmanın örneklemi belirlenirken kolay ulaşılabilir durum örneklemesi yöntemi kullanılmıştır. Kolay ulaş1labilir durum örneklemelerinde çalışmanın pratik ve hızlı şekilde yürütülebilmesi için yakın ve ulaşılması kolay bir örneklem grubu seçilir (Patton, 2002). Buna göre örneklemde Karadeniz Teknik Üniversitesi Fatih Eğitim Fakültesi okul öncesi öğretmenliği ana bilim dalında eğitimini sürdürmekte olan 8 adet 4 . Sınıf öğrencisi yer almıștır. 


\section{Verilerin Toplanmast}

Araştırmanın verileri odak grup görüşmesi ile elde edilmiştir. Odak grup görüşmesi benzer özelliklere sahip kişilerin oluşturduğu küçük gruplar için tasarlanmış ve belli konudaki düşünce ve fikirleri ayrıntılı bir şekilde ortaya çıkartmayı amaçlayan görüşme tekniğidir (Berg, 2001). Araştırmada öğretmen adaylarının grup ortamında istenmeyen davranışlara ilişkin daha somut örnekler verebilmesi ve kendilerini sorguya çekiliyormuş hissi olmadan rahat ifade edebilmeleri için odak grup görüşmesi kullanılmıştır. Örneklem seçiminden sonra görüşme yapılacak odak grup oluşturulmuş ve bu grupla 3 oturum halinde görüşmeler yapılmıştır. Tüm görüşmeler video kayıt cihazı ile kayıt altına alınmış ve daha sonra araştırmacılar tarafından yazıya dökülmüştür.

\section{Verilerin Analizi}

Araştırmadan elde edilen veriler, yazılı dökümleri yapıldıktan sonra nitel veri analiz aracı olan NVivo 8 programına aktarılarak içerik analizi ile çözümlemesi yapılmıştır. İçerik analizinde yapılan işlem, birbirine benzeyen verileri belirli kavramlar ve temalar çerçevesinde bir araya getirmek ve bunları okuyucunun anlayacağı biçimde düzenleyerek yorumlamaktır (Yıldırım ve Şimşek, 2006). Programa yüklenen yazılı metinlerin satır satır okunması ve veriler arasında yer alan anlamlı bölümlerin kodlanmasında önceden belirlenen genel çerçeveden yararlanılmış ve NVivo 8 programı aracılığı ile kodlamalar işaretlenmiştir. $\mathrm{Bu}$ kodlamalar: sınıf yönetimine yönelik dersler, karşılaşılan istenmeyen davranışlar, istenmeyen davranışları önleme yolları, istenmeyen davranışları ortadan kaldırma yolları, öğretmen adaylarının geliştirdikleri stratejiler şeklinde oluşturulmuştur. Oluşturulan kodlamalar yorumlanarak bulgular elde edilmiştir.

\section{Bulgular}

$\mathrm{Bu}$ bölümde sınıfta istenmeyen davranışlar ve disiplin ile ilgili okul öncesi öğretmen adaylarıyla yapılan odak grup görüşmelerinden elde edilen bulgulara ve yorumlara yer verilmiştir. Bulgular Okul öncesi öğretmen adaylarının sınıf yönetimi konusunda aldıkları eğitimler ve okul öncesi eğitim sınıfında ortaya çıkabilecek istenmeyen davranışlar ve başa çıkma stratejileri ve olmak üzere 2 başlık altında incelenmiştir. 


\section{Okul öncesi öğretmen adaylarının sınıf yönetimi konusunda aldıkları eğitimler}

Çalışmaya katılan sekiz öğretmen adayının üniversite eğitimi sırasında sınıf yönetimine yönelik aldıkları dersler ve sınıfta istenmeyen davranışları önleyebilmeye yönelik aldıkları eğitimlerle ilgili ifadeleri gruplandırılmış ve tablo.1' de görülen dağılım oluşturulmuştur.

Tablo 1. Öğretmen adaylarının sınıf yönetimine yönelik dersler ve sınıfta istenmeyen davranıșları önleyebilmeye yönelik eğitimlerle ilgili ifadeleri

\begin{tabular}{|c|c|c|c|c|c|c|c|c|}
\hline & $\begin{array}{c}\mathbf{K} \\
\mathbf{1}\end{array}$ & $\begin{array}{l}\mathbf{K} \\
2\end{array}$ & $\begin{array}{l}\mathbf{K} \\
\mathbf{3}\end{array}$ & $\begin{array}{l}\mathbf{K} \\
\mathbf{4}\end{array}$ & $\begin{array}{l}\mathbf{K} \\
5\end{array}$ & $\begin{array}{l}\mathbf{K} \\
\mathbf{6}\end{array}$ & $\begin{array}{l}\mathbf{K} \\
7\end{array}$ & $\begin{array}{l}\mathbf{K} \\
\mathbf{8}\end{array}$ \\
\hline Ders içerikleri okul öncesine uygun değildi & & $\mathrm{x}$ & $\mathrm{x}$ & $\mathrm{x}$ & & $\mathrm{x}$ & $\mathrm{x}$ & $\bar{x}$ \\
\hline Derslerin uygulama yönü yetersizdi & $\mathrm{x}$ & $\mathrm{x}$ & & $\mathrm{x}$ & $\mathrm{x}$ & $\mathrm{x}$ & & \\
\hline $\begin{array}{l}\text { Dersler uygulama biçimi nedeniyle sınıf yönetimi } \\
\text { becerileri kazandırmada etkisiz kalıyordu }\end{array}$ & $\mathrm{x}$ & & $\mathrm{x}$ & $\mathrm{x}$ & $\mathrm{x}$ & & $\mathrm{x}$ & $\mathrm{x}$ \\
\hline $\begin{array}{l}\text { Dersler içerik nedeniyle sınıf yönetimi becerileri } \\
\text { kazandırmada etkisiz kalıyordu }\end{array}$ & $\mathrm{x}$ & $\mathrm{x}$ & $\mathrm{x}$ & & $\mathrm{x}$ & $\mathrm{x}$ & $\mathrm{x}$ & $\mathrm{x}$ \\
\hline
\end{tabular}

Öğretmen adaylarından K3 üniversite eğitimi sırasında aldıkları "sınıf yönetimi” dersiyle ilgili olarak “ Sınıf yönetimi dersinde hep ilköğretime yönelik yöntemler gösteriliyor ama öğretmenlik uygulamasına gittiğimizde hiç birini bizim sınıflarımıza uygulamamız mümkün olmuyor. Bizim sınıf yönetimi dersini okul öncesi alanında hocalardan almamız lazım ki ne yapmamız gerektiğini bilelim” şeklinde yorum yapmıştır. Bir diğer öğretmen adayı K1 "kitaptan bazı şeyleri okuyup öğreniyoruz ya da hocanın anlatmasıyla ama sınıfa gidip çocukları görünce mesela ben ne yapacağımı bilemedim, şaşırıp kaldım" diyerek sınıf yönetimi derslerinin uygulama yönünün eksik kaldığına vurgu yapmıştır. Öğretmen adaylarından K5 ise "derslerde bize anlatılan birçok durumla sınıfta karşılaşıyoruz fakat bunlarla başa çıkabilmek için yapabilecek bir şey bulamıyorum. Okulda öğrendiğim başa çıkma yollarının çoğunu o an ki duruma örtüştüremiyorum" şeklinde bir yorumda bulunarak sınıf yönetimi ve sorun davranışlar ile başa çıkma konusunda kendisini ve aldığı eğitimi eksik bulduğunu ortaya koymuştur. K4 kodlu öğretmen adayı derslerin uygulama yönüyle eksik kaldığını ve işlenişte değişiklikler yapılabileceğine dair görüşlerini belirtmek için şu ifadeleri kullanmıştır; “ sınıf yönetimi dersi bence çok daha farklı şekilde işlenebilir. Mesela biz stajlara gidiyoruz veya çevremizde bazı olaylarla karşılaşıyoruz. Bu gibi durumları örnek olaylar olarak sınıfa getirip, bu sorunların çözüm 
önerilerini tartışabiliriz, örnek olaylar üzerinden konuları işlesek hem alanımıza daha uygun olur hem de daha faydalı olur diye düşünüyorum."

Okul öncesi eğitim sınıfinda ortaya çıkabilecek istenmeyen davranışlar ve başa çıkma stratejileri

Öğretmen adaylarının sinıflarda en sik görülen istenmeyen davranışlar konusundaki görüşleri incelenmiş ve istenmeyen davranışları ifade etme sıklıkları tablo 2'de görüldüğü gibi olmuştur.

Tablo 2. Öğretmen adaylarının istenmeyen davranıșları ifade etme sıklığı

\begin{tabular}{|c|c|c|c|c|c|c|c|c|}
\hline & K1 & K2 & K3 & K4 & K5 & K6 & K7 & K8 \\
\hline İlgisiz olma & & 1 & 1 & 1 & & 1 & 1 & 1 \\
\hline İnatlaşma & 1 & 1 & & & 1 & 1 & & \\
\hline $\begin{array}{l}\text { Saldırganlık- asi } \\
\text { davranışlar }\end{array}$ & 1 & & 1 & & & & 1 & 1 \\
\hline $\begin{array}{l}\text { Kendine veya } \\
\text { arkadaşına zarar } \\
\text { verme }\end{array}$ & & & 1 & & & 1 & & 1 \\
\hline $\begin{array}{l}\text { Yemek yeme } \\
\text { problemleri }\end{array}$ & & & 1 & & 1 & & & \\
\hline Ağlama-bağırma & & 1 & & 1 & & & & \\
\hline TOPLAM & 2 & 3 & 4 & 2 & 2 & 3 & 2 & 3 \\
\hline
\end{tabular}

Öğretmen adaylarının istenmeyen davranışlar hakkında görüşleri incelendiğinde adayların en sık karşılaştığını ifade ettiği davranış “ilgisiz olma” davranışıdır. Bu davranışla ilgili olarak K3 kodlu öğretmen adayı "staja gittiğimiz sınıfta 2 çocuk var sürekli ben yapmak istemiyorum, oyun oynamayacağım gibi ifadeler kullanarak köşelere çekiliyor. Öğretmen onları etkinliğe katmak istediğinde ise ya hırçınlaşıyorlar ya da etkinliği özensiz bir şekilde yapıyorlar" şeklinde ifadeler kullanmıştır. Sadece iki öğretmen adayının karşılaştı̆̆ını söylediği "ağlama-bağırma" davranışı ile ilgili olarak K2 kodlu ögretmen adayı "uygulama sınıfımda çocuklarda genel olarak istedikleri olmayınca ağlama davranışı var. Sanırım birbirlerinden görüp bu davranışı iyice pekiştirmişler” demiştir.

K4 kodlu öğretmen adayı ise "çocuklar iletişim kurarken sürekli bağırıyorlar, oyun oynarken ya da etkinlik yaparken sürekli bir gürültü 
var. Öğretmende sesini yükselterek konuşmak zorunda kalıyor ama ben hala alışamadım” şeklinde görüş belirtmiştir.

Belirtilen istenmeyen davranışları önleme ve ortadan kaldırmaya yönelik görüşler incelendiğinde sınıfta istenmeyen davranışların görülmesini önleme amacıyla velilerle iş birliği yapılıp birlikte ve tutarlı hareket edilmesi ve çocukları iyi tanıyıp, doğru iletişim kurulması gerektiği görüşleri ön plana çıkmıştır. Öğretmen adaylarının belirttiği istenmeyen davranışlar ile baş edebilme stratejilerini öğrenme yolları da sınıflandırılmış ve tablo.3 oluşturulmuştur.

Tablo 3. İstenmeyen davranışlar ile baş edebilme stratejilerinin dağılımı

\begin{tabular}{|c|c|c|c|}
\hline & $\begin{array}{c}\text { Kendi } \\
\text { oluşturdukları/ } \\
\text { öğretmen } \\
\text { adayının pratik } \\
\text { bilgisi }\end{array}$ & $\begin{array}{c}\text { Lisans } \\
\text { eğitiminde } \\
\text { öğrendikleri }\end{array}$ & $\begin{array}{c}\text { Staj } \\
\text { uygulamasında } \\
\text { öğrendikleri }\end{array}$ \\
\hline Velilerle iş birliği yapmak & & & $\mathrm{X}$ \\
\hline $\begin{array}{l}\text { Veliyle birlikte hareket edip } \\
\text { tutarlı davranmak }\end{array}$ & & $\mathrm{x}$ & $\mathrm{x}$ \\
\hline Çocukları iyi tanımak & & $\mathrm{x}$ & \\
\hline $\begin{array}{l}\text { Çocuklarla samimi ve doğru } \\
\text { iletişim kurabilmek }\end{array}$ & & & $\mathrm{x}$ \\
\hline $\begin{array}{l}\text { Etkinlikleri daha görsel hale } \\
\text { getirip somutlaştırmak }\end{array}$ & $\mathrm{x}$ & & \\
\hline $\begin{array}{l}\text { Çocukların ilgisini sürekli } \\
\text { canlı tutmak ve bunu } \\
\text { pekiştirmek }\end{array}$ & $\mathrm{x}$ & & \\
\hline $\begin{array}{l}\text { Çocuğun kendini ifade etmesi } \\
\text { ve içindekini ortaya } \\
\text { çıkarmasına yardım etmek. }\end{array}$ & $\mathrm{x}$ & & $\mathrm{X}$ \\
\hline $\begin{array}{l}\text { Çocukların ilgisine göre esnek } \\
\text { olmak }\end{array}$ & $\mathrm{x}$ & & \\
\hline Görmezden gelmek & & $\mathrm{x}$ & \\
\hline Model olmak & & $\mathrm{x}$ & $\mathrm{X}$ \\
\hline
\end{tabular}

Tablo 3’te görülen öğretmen adaylarının görüşlerine göre istenmeyen davranışlar ile baş edebilme stratejilerinin geliştirilmesinde staj uygulamalarının, lisans eğitimlerine ve adayların pratik bilgisine göre daha etkili olduğu ve staj uygulamalarının yetersiz kaldığı durumlarda öğretmen adaylarının kendi stratejilerini oluşturdukları görülmüş̧ür. Örneğin Tablo 2'ye göre sınıfta en sık görülen istenmeyen davranış olan "ilgisiz olma" davranışının ortadan kaldırılmasına yönelik stratejilerin tablo.3'te öğretmen adaylarının kendi oluşturdukları stratejiler kategorisinde sınıflandığı görülmüsstür. 


\section{Sonuç ve Tartıșma}

Çalışmadan elde edilen bulgular sonucunda öğretmen adaylarının üniversite eğitimleri sırasında aldıkları dersler konusunda kendilerini eksik hissettikleri ve bu alanda ihtiyaç duydukları bilgileri staj uygulamalarında ki uygulama öğretmenlerini gözlemleyerek edinmeye çalıştıkları ortaya çıkarılmıştır. Öğretmen eğitimi programlarının uygulama etkinlikleri ile işlevsel hale getirilmesiyle öğretmen adaylarının edindikleri bilgi ve becerileri meslek yaşamlarında bilerek ve güvenle kullanması mümkün olmaktadır (Çoban, 1999). Çalışma bulgularına göre ise üniversite eğitimi sırasında alınan derslerin daha çok teorik boyutta kalmasının öğretmen adaylarının gerekli tecrübeleri edinememesine yol açtığı görülmüş̧ür.

Çalışmaya katılan öğretmen adaylarının görüşlerine göre sınıfta görülen istenmeyen davranışların önlenmesi ve ortadan kaldırılmasında aile ve öğretmenin iş birliği içinde olmasının önemli olduğu fakat sınıf disiplini ve yönetiminde öğretmenin bilgi, beceri ve tecrübesinin etkili olduğu ve ögretmen davranışlarına göre çocukların davranışlarının şekillendiği görülmüştür. Bu durumda öğretmen adaylarının mesleğe başlamadan gerekli bilgi ve tecrübeleri kazanmasın ve kendini geliştirmesinin önemi ortaya çıkmaktadır. Lewis ve Doorlag (1991) çalışmalarında bazı uygun olmayan öğrenci davranışlarının öğretmenlerin uygulamalarından dolayı ortaya çıkabileceğini belirtmişlerdir. Yapılan bu çalışmada da öğretmen davranıșlarının öğrenci davranıșlarını etkilediği görülmüștür.

Öğretmen adayları derslerden beklentilerini ifade ederken sınıf yönetimine yönelik derslerin içerik olarak yeterli gelmediğini ve içeriklerin genel olarak okul öncesi eğitim sınıflarına uygun olmadığını belirtmişlerdir. Early ve arkadaşları (2006) ise yaptıkları çalışmada okul öncesi öğretmenlerinin aldıkları eğitimlerinin çocukların zihinsel ve genel becerileri üzerine etkisinin olduğunu tespit etmişlerdir.

İstenmeyen davranışların belirlenmesi ile ilgili öğretmen adaylarının ifadeleri incelendiğinde "ilgisiz olma", "saldırganlık-asi davranışlar" ve "inatlaşma” davranışlarının sık görülen istenmeyen davranışlar olarak ön plana çıktığı görülmüştür. Bu alanda yapılan çalışmalar incelendiğinde kaynakların "ilgisiz olma, hiçbir şey yapmama” gibi davranışlar ile sık karşılaşılmadığı ve bu davranışların genelde öğretmenin çocukların kişisel özelliklerini tam olarak kavrayıp doğru yöntemi kullanamamasından kaynaklandığını belirttiği görülmüştür (Kapucuoğlu Tolunay, 2008). Ortaya çıkan bu farklı durumun çalışmaların yapıldığı bölgelerin kültürel açıdan birbirinden 
farklı olması veya çalışma grubunda ki çocukların yaş ve gelişim özellikleri açısından birbiriyle aynı olmamasından kaynaklandığı düşünülmektedir.

Öğretmen adayları "okul deneyimi” dersi ve staj uygulamalarındaki tecrübelerinden yola çıkarak bu ifadeleri kullanmış olduklarını belirtmişlerdir. Adayların bu ifadelerinde gözlemledikleri sınıfın ve öğretmenin etkisi olabileceği düşünülmektedir. Öğretmen adaylarının uygulama öğretmenini model aldığı ve uygulama yapılan sınıf öğretmeninin öğretmen adayı için iyi örnek olması gerektiği yapılan çalışmalarda vurgulanmıştır (Ünver, 2003).

\section{Öneriler}

Araştırma sonuçlarına göre, öğretmen adaylarının aldıkları eğitimler ve yapılabilecek çalışmalarla ilgili şu önerilerde bulunulabilir:

- Eğitim fakültelerinin okul öncesi eğitim öğretmenliği bölümlerinde uygulamalı ders saatleri ve öğretmenlik uygulaması derslerinin saatleri artırılabilir. Öğretmen adaylarının tecrübelerinin artırılması onların mesleklerine ilişkin öz farkındalığını artıracaktır.

- Eğitim fakültelerinde genel olarak tüm bölümlere aynı müfredatla verilen sınıf yönetimi ve benzeri derslerin içerikleri bölümlerin gereksinimlerine göre yeniden şekillendirilebilir. Uygulama örneklerini yansitıcı eğitim etkinlikleri ile pekiştirilebilir.

- Çalışma farklı üniversitelerden oluşturulan öğrenci grubu ile yapılarak farklı üniversitelerdeki uygulamalara ilişkin sonuçlar alınması sağlanabilir.

\section{Kaynaklar}

Akar, H., Tor, D., Tantekin-Erden, F., ve Şahin, İ.T. (2010) . Öğretmenlerin Sınıf Yönetimi Yaklaşımları ve Deneyimlerinin İncelenmesi, Illköğretim Online 
http://ilkogretim-online.org.tr adresinden 10 Mart 2011 tarihinde edinildi. , 9(2), 792-806.

Akbaşlı, S., Yanpar-Yelken, T., \& Sünbül, Ö. (2010). Öğretmen Adayı Demokratik Eğilim Ölçeği Geliştirme Çalışması. Uluslararası Avrasya Sosyal Bilimler Dergisi, 1(1), 94-108.

Aktaş Arnas,Y. ve Sadık, F. (2008). Okul Öncesi Eğitimde Sınıf Yönetimi, Kök Yayınc1lık,1. Baskı, Ankara.

Balay , R., ve Sağlam , M. ( 2008). Sınıf İçi Olumsuz Davranışlara İlişkin Öğretmen Görüşleri. Yüzüncü Yll Üniversitesi Eğitim Fakültesi Dergisi, 5, 1-24.

Başal, H.A. (2005). Okul Öncesi Eğitiminin İlke ve Yöntemleri, Morpa Kültür Yayınları, Genişletilmiş 2. Baskı, İstanbul.

Berg, B.L. (2001). Qualitative Research Methods For The Social Sciences, Allyn And Bacon, 4. Bask1, Needham Heights, MA, ABD.

Bilir, Ş. (1993). Okul Öncesi Eğitimin Önemi ve Yararları, Okul Öncesi Eğitimi, M. E. B. Okul Öncesi Eğitim Genel Müdürlüğü Yayınları, Ankara.

Çoban, A. (1999). 21. Yüzyıla Girerken Öğretmen Eğitiminin Boyutları. Milli Ĕ̈itim Dergisi (140): 84-87.

Denizel-Güven, E. ve Cevher, F.N. (2005). Okul Öncesi Öğretmenlerinin Sınıf Yönetimi Becerilerinin Çeşitli Değişkenler Açısından İncelenmesi. Pamukkale Üniversitesi Eğitim Fakültesi Dergisi,2 (18), 1-22.

Dönmez, B.\&Cömert, M.(2009) Öğretmen Adaylarının, Kendilerinin Ve Uygulama Öğretmenlerinin Sınıf İçi İstenmeyen Öğrenci Davranışları İle Baş Etme Konusundaki Yeterliklerine İlişkin Algıları, Ahi Evran Üniversitesi Eğitim Fakültesi Dergisi,10(2), 47-55.

Early, D. M., Bryant, D. M., Pianta, R. C., Clifford, R. M., Burchinal, M. R., Ritchie, S., Howes, C., Barbarin, O. (2006). Are teachers' education, major, and credentials related to classroom quality and children's academic gains in pre-kindergarten? Early Childhood Research Quarterly, 21(2), 174-195.

Ekici, G. (2008). Sınıf Yönetimi Dersinin Öğretmen Adaylarının Öğretmen Öz Yeterlik Alg1 Düzeyine Etkisi, Hacettepe Üniversitesi Eğitim Fakültesi Dergisi, sy. 35, ss. 98-110.

Erkan, S., Severcan, S. (2010). Okul Öncesi Öğretmen Adaylarının Uygulama Yaptıkları Kurum Türüne Göre Öğretmenlik Uygulamasını Mesleki Kazanımlar Açısından Değerlendirmeleri, Çă̆daş Eğitim Dergisi, sy. 35, ss. 6-14. 
Gezgin, N. (2009). Okul Öncesi Eğitimi Öğretmenlerinin Kullandıkları Sınıf Yönetimi Stratejileri, Uludağ Üniversitesi Sosyal Bilimler Enstitüsü, Bursa.

Güleç, S. ve Alkış, S. (2004) .Öğretmenlerin Sınıf Ortamında Kullandıkları Davranış Değiștirme Stratejileri. Uludă̆ Üniversitesi Ĕ̆itim Fakültesi Dergisi,17,247-266.

Güven, E.D., Cevher, F. N. (2005). Okul Öncesi Öğretmenlerinin Sınıf Yönetimi Becerilerinin Çeşitli Değişkenler Açısından İncelenmesi, Pamukkale Üniversitesi Eğitim Fakültesi Dergisi, c. 2, sy.18, ss. 1-22,.

İlgar, L. (2007). İlköğretim Öğretmenlerinin Sınıf Yönetimi Becerileri Üzerine Bir Araştırma. ( Yayımlanmamış doktora tezi). İstanbul Üniversitesi, İstanbul.

Kapucuoğlu Tolunay, A. (2008). Sınıf öğretmenlerinin sınıfta karşılaştıkları istenmeyen öğrenci davranışları ve bu davranışlara karsı kullandıkları baş etme yöntemleri. Yayımlanmamış Yüksek Lisans Tezi, Uludağ Üniversitesi Sosyal Bilimler Enstitüsü, Bursa.

Kazu, H. (2007).Öğretmenlerin Sınıfta İstenmeyen Davranışların Önlenmesi Ve Değiştirilmesine Yönelik Stratejileri Uygulama Durumları. Milli Ĕğitim Dergisi, 175,57-66.

Kök, M., Çiftçi, M. Ve Ayık,A. (2011). Öğretmenlik Mesleği Özel Alan Yeterliklerine İlişkin Bir İnceleme (Okul Öncesi Öğretmenliği Örneği), Atatürk Üniversitesi Sosyal Bilimler Enstitüsü Dergisi, sy.15, ss.169-183.

Kvale, S. (1996). InterViews: An introduction to qualitative research interviewing. Thousand Oaks, CA: Sage.

Lewis R. B. D. ve Doorlag, H. D. (1991). Teaching Special Students In the Mainstream. NewYork: Macmillian

Özbey, S. ve Alisinanoğlu, F. (2009) Okul Öncesi Eğitim Kurumuna Devam Eden 60-72 Aylık Çocukların Problem Davranışlarının Bazı Değişkenlere Göre İncelenmesi. Uluslararası Sosyal Araştırmalar Dergisi, vol 216, 493-518.

Özgün, Ö.(2008). Sınıfta İstenmeyen Davranışlar, Nedenleri, Yönetimi. Yaşare Aktaş Arnas\& Fatma Sadık(Ed.) , Okul Öncesi Eğitimde Sınıf Yönetimi içinde (s.243-276). Ankara: Kök Yayıncılık.

Öztürk, Y. (2010). Early Childhood Education Policy Development in Turkey: A case study of the General Directorate of Preschool Education in the context of negotiating modernity and seeking European Union membership. Germany: VDM Publishing.

Patton, M.Q. (2002). Qualitative Research\& Evaluation Methods, Sage Publications, 3. Bask1, California, ABD. 
Sadık, F. (2004). Okul Öncesi Sınıflarda Gözlenen Problem Davranışlar ve Bu Davranışlarla Baş etmede Öğretmenlerin Kullandıkları Yöntemler, Ĕ̆itim Araştırmaları Dergisi, sy. 13, ss. 89-97.

Sadık,F. (2008) İstenmeyen Davranışlarla Baş Etme Stratejilerinin Öğretmen ve Öğrenci Görüşlerine Göre İncelenmesi, Ilkögretim Online , http://ilkogretim-online.org.tr adresinden 10 Mart 2011 tarihinde edinildi. , 7(2), 232-251.

Şahin, H., Ogelman,H.G. ve Ekici,G. (2011) Okul Öncesi Öğretmen Adaylarının Akademik Öz-Yeterlik Düzeylerine Etki Eden Faktörlerin Değerlendirilmesi, Çă̆daş Eğitim Dergisi, sy.36, ss.13-22.

Uysal,H., Akbaba-Altun, S. ve Akgün, E. (2009, Ekim). Okulöncesi Öğretmenlerinin Çocukların İstenmeyen Davranışları Karşısında Uyguladıkları Stratejiler. Bu çalışma, Ege Üniversitesi 18. Eğitim Bilimleri Kurultayı'nda bildiri olarak sunulmuştur, Kuşadası, Aydın.

Ünver, G. (2003). Öğretmenlik Uygulamasında İşbirliği :Bir Durum Çalışması. Gazi Ĕ̌itim Fakültesi Dergisi, 23 (1), 87-100.

Yavuzer, H. (2006). Çocuk Eğitimi El Kitabı. İstanbul: Remzi Kitabevi.

Yıldırım, A. ve Şimşek, H. (2006). Sosyal Bilimlerde Nitel Araştırma Yöntemleri. Ankara, Seçkin Yayıncılık. 


\section{Extended Summary}

The Impact of Teaching Education Program on Pre-service Teachers' Classroom Management Views and Classroom Management Strategies

\section{Purpose}

This study aims to investigate the effect of pre-service teachers' education and student teaching on their views about classroom management, classroom management strategies and skills, and problem solving skills. The following questions were specifically sought through this study:

- How do pre-service teachers view their education regarding classroom management?

- How do pre-service teachers recognize problem behaviors in the classroom environment and what are their strategies to deal with problem behaviors?

- How do teacher education and student teaching affect pre-service teachers' views, beliefs and efficacy regarding classroom management?

\section{Method}

Case study, a form of qualitative research, is used as the research method in this study. Participants of this study included 8 senior pre-service teachers studying in Early Childhood Teacher Education Program at Karadeniz Technical University in 2011-2012 academic year. Data were collected through three focus group interviews. Focus group interview is conducted because it stimulates dialogues among participants and allows researchers to gather in-dept data (Berg, 2001; Kvale, 1996 Patton, 2002). Interviews were video-recorded and later transcribed for coding and analysis. Nvivo 8 program, a qualitative and mixed method analysis tool, is used to code and analyze the data. Furthermore, thematic content analysis is utilized.

\section{Results}

Findings of this study are presented under two themes. The first theme is formed as pre-service teachers' education about classroom management; and the second theme is formed as 'pre-service teachers' views of the most common problem behaviors in an early childhood classroom and teachers' management strategies'.

\section{Discussion}

Pre-service teachers participated in this study felt that the knowledge they gained during their study in the program is not put into practice, therefore they were observing their classroom teacher during their student teaching to learn more through practice. It is known that if pre-service teachers are given the opportunity to put theoretical knowledge into practice before they enter the teaching profession, they use their knowledge and skills more effectively in the profession (Çoban, 1999).

Another underlined result of this study is participants believe that the content of the classroom management course(s) they have taken in the program are not well suited to early childhood education.

Pre-service teachers participated in this study stated 'aggressive', 'stubborn', and 'uninterested' behaviors as the most common problems encountered in an early childhood classroom. They stated these problem behaviors based on their experiences gained during their student teaching. Moreover, they believe that teachers' knowledge, skills and experience are important aspects in an effective 
classroom management. Even though teachers' collaboration with parents is also important to deal with problem behaviors, pre-service teachers believe that teachers' management strategies and skills are more critical. Therefore, it can be concluded that pre-service teachers' experience about classroom management is very crucial before they enter the profession.

\section{Conclusion}

This study revealed that pre-service teachers' classroom management education is too theoretical and pre-service teachers graduate with inadequate practice on the subject. Moreover, study showed that teachers' classroom management strategies and skills are crucial to dealing with problem behaviors encountered in early childhood classroom. Thus, this study's results show a need to increase the amount of student teaching hours required in the program. Furthermore, content of the classroom management classes offered in the programs should be revised and these courses should be more practice based rather than theory based. 